\title{
DO ABJECIONISMO AO NEO-ABJECIONISMO: PERSPETIVAS SOBRE A LIBERTAÇÃO E A EXEMPLARIDADE DO AUTOR
}

FROM ABJECTIONISM TO NEO-ABJECTIONISM: PERSPECTIVES ON THE AUTHOR'S LIBERATION AND EXEMPLARITY

http://dx.doi.org/10.11606/issn.2175-3180.v12i22p136-169

Rui Daniel Sousa ${ }^{\mathrm{I}}$

\section{RESUMO}

Este texto propõe-se apresentar um panorama do Abjecionismo em Portugal, focando os discursos de quatro autores fundamentais: António Maria Lisboa, Pedro Oom, Mário Cesariny e Luiz Pacheco. Analisam-se textos programáticos particularmente marcantes, nos quais os autores propõem as diversas interpretações da vertente abjecionista. Apesar das controvérsias quanto ao verdadeiro sentido do Abjecionismo e às suas interações com o contexto social, político e literário da época, as diferentes perspetivas apontam para uma definição do criador literário que tem na libertação progressiva e no questionamento da condição humana os seus principais vetores.

\section{PALAVRAS-CHAVE}

Abjecionismo; Libertino; Exemplaridade; Libertação; Surrealismo.

\section{ABSTRACT}

This paper aims to present an overview of Portuguese Abjectionism, focusing on three main authors: António Maria Lisboa, Pedro Oom, Mário Cesariny and Luiz Pacheco. We propose to present different interpretations of abjectionist discourse through some programmatic texts. Despite the controversies regarding the true meaning of Abjectionism and its interactions with the social, political and literary context of the time, the different perspectives point to a definition of the literary creator whose main vectors are the progressive liberation of the individual and the questioning the human condition.

\section{KEYWORDS}

Abjectionism; Libertine; Exemplarity; Liberation; Surrealism.

I Universidade de Lisboa, Lisboa, Portugal. 
Entre o final da década de 40 e os primeiros anos da década de 70, o conceito de Abjecionismo constituiu-se como um dos mais persistentes motivos de discussão por parte dos representantes do movimento surrealista em Portugal, contribuindo para exprimir diferentes pontos de vista a respeito do ambiente social, político e cultural vivido e do posicionamento do indivíduo face a esse contexto. Considerado por poetas e escritores fundamentais como António Maria Lisboa, Pedro Oom, Mário Cesariny e Luiz Pacheco, o Abjecionismo foi conhecendo uma notável plasticidade, adaptando-se a diferentes momentos e correspondendo a diferentes interpretações do devir surrealista em Portugal e de projetos criadores particulares, de uma forma ou de outra associados à atmosfera libertadora propiciada pelo influxo surrealista.

Não sendo propósito deste texto discutir as diferentes perspetivas da crítica sobre o Abjecionismo, nomeadamente ao nível da delimitação cronológica deste e das suas intrincadas relações com o Surrealismo, a argumentação que propomos parte do princípio de que o conceito de abjeção, na linha de propostas teóricas de André Breton, Antonin Artaud e Georges Bataille. Importa ainda assim que comecemos por reter alguns tópicos mais salientes do percurso hermenêutico do conceito antes de abordarmos mais demoradamente o ponto de vista do qual partimos.

Com efeito, pode referir-se uma relativa controvérsia quanto ao verdadeiro sentido do Abjeccionismo, sobretudo quanto à sua pertinência, aos seus limites cronológicos e às suas relações com o Surrealismo. Numa breve síntese, encontram-se as seguintes teses predominantes:

1. O ABJECCIONISMO COMO EXPERIÊNCIA DE LIBERTAÇ̃̃O. Neste sentido, o Abjeccionismo é entendido como reivindicação de uma liberdade extrema, relacionada com o importante impulso agregador representado pela herança surrealista numa geração situada numa espécie de beco face às diversas ideologias em choque no final da década de 40 e, em particular, ao regime totalitário autoimposto, mas também com a necessidade de distanciamento crítico face ao próprio movimento surrealista de cunho bretoniano e ao contacto com outros autores dissidentes da via aberta por Breton, como Georges Bataille, Antonin Artaud, Michel Leiris, Robert Desnos, entre outros. Perfecto Cuadrado lembra esse momento como uma 
"coincidência com o relançamento mundial do surrealismo", associando a organização de grupos surrealistas portugueses a uma necessidade internacional (CUADRADO, 2017, p. 58).

\section{O ABJECCIONISMO COMO EXPRESSÃO DAS INQUIETAÇ̃̃ES MODERNISTAS E VANGUARDISTAS EM PORTUGAL. Circunscrevendo o Abjeccionismo aos} importantes desenvolvimentos da literatura e da cultura portuguesas desde o início do século XX, esta leitura tende a ser relacionada com as mais provocatórias repercussões do Modernismo e das Vanguardas em Portugal, num um certo ethos surrealista tipicamente português. Nesta medida, o Abjeccionismo corresponderia a uma resposta adequada a procedimentos e inquietações ontológicas recorrentes na cultura portuguesa desde o final do século XIX, relacionados com o embate e o apelo à autonomia absoluta por parte dos artistas e as instituições normalizadoras da sociedade. No Surrealismo-Abjeccionismo, como no próprio discurso dos representantes da geração de Orpheu, estaríamos perante um movimento que se processa como "passeio pelas diversas vanguardas - ou ismos -, sem, no entanto, deixar-se fixar ou rotular por nenhum deles" [MARTUSCELLI, 2013, p. 198; cf. também CUADRADO (1998, p. 9) e MARTINS (2016, em particular p. 23-33)].

\section{O ABJECCIONISMO COMO EXPRESSÃO PARTICULAR DO SURREALISMO} PORTUGUÊS. O Abjeccionismo tende, por vezes, a ser identificado com uma das muitas manifestações possíveis do fenómeno surrealista em Portugal, integrando-se de forma particularmente veemente no cerne do desenvolvimento polémico e marcado por contínuas guerrilhas que caracterizou a evolução do Surrealismo em Portugal. Um exemplo representativo desta tese encontra-se em E. M. de Melo e Castro, que faz das várias facetas implicadas no decurso surrealista português um emblema das múltiplas vias de rutura relativamente a uma mundividência esgotada, acrescentando que a possibilidade abjeccionista coincide com uma espécie de radicalismo satanista do Surrealismo, também em cisão relativamente aos pontos de vista de André Breton (CASTRO, 1987, p. 66). Para Clara Rocha, essa forte presença da abjeção e da sobrerrealidade é colocada no mesmo patamar da outra via pela qual se operou a recusa surrealista do Realismo em arte, a Surrealidade diretamente derivada das 
propostas de Breton e dos seus mais próximos seguidores (ROCHA, 2002, p. 142-145).

\section{O ABJECCIONISMO COMO 'EXIBICIONISMO MISERABILISTA'. Situando-se}

numa posição crítica que, embora dialogue com as anteriormente apresentadas, reage negativamente a alguns dos seus argumentos e conduz outros numa direção que demarca o Abjeccionismo sem o fazer à luz de uma deriva interna do movimento surrealista, Perfecto E. Cuadrado insiste na necessidade de ler as teses que referem a corrente abjeccionista como "um surrealismo tipicamente português" através de um enfoque colocado no adjetivo - a remissão explícita para o contexto português mas desligado do substantivo - a pertença ao Surrealismo propriamente dito. Perfecto Cuadrado opta por considerar o Abjeccionismo "uma síntese entre a denúncia neo-realista (um neo-realismo que mostrasse a sua face mais anti-heróica sem o querer nem o desejar" e outras componentes mais propriamente tradicionais, "a angústia de uma interrogação quase existencialista sobre o poder da literatura e da arte (...) e o que poderíamos chamar 'exibicionismo miserabilista'", identificado com Henry Miller, com o expressionismo alemão e com o dadaísmo (CUADRADO, 2017, p. 56-60).

\section{O ABJECCIONISMO E O GRUPO DO CAFÉ GELO. O Abjeccionismo estaria} particularmente relacionado com o segundo momento da aventura surrealista situada no contexto português, que, a partir de meados da década de 60 e, grosso modo, até a publicação de Grifo (1970), prosseguiu uma actividade dispersa, irredutível a agrupamentos, mesmo que heterodoxos, e mais condicionada pelo agravamento da realidade sociopolítica vigente. Esta etapa coincide, também, com uma série de desenvolvimentos significativos em termos internacionais, antecipando, segundo alguns hermeneutas, o essencial do espírito contracultural característico das Vanguardas históricas das décadas de 60 e de 70 . José Augusto Mourão, por exemplo, integra a via abjeccionista numa linhagem vasta, ligada com a tradição dos "poetas malditos", com as primeiras manifestações vanguardistas, como o Dadaísmo, e com movimentos da segunda metade do século, como o Existencialismo, o Teatro do Absurdo, a Beat Generation e as repercussões de tudo isso em Portugal (MOURÃO, 2002, p. 31-38). Na mesma linha, Fernando Guimarães salienta a perenidade dos influxos abjeccionistas nas mais marcantes antologias e 
coleções poéticas portuguesas desde a década de 80, em particular nas mais deliberadamente alheias aos circuitos literários convencionais (Idem, ibidem, p. 140-141; cf. também GUIMARÃES, 2004, p. 143-154).

Traçado um breve panorama, importa salientar que, quanto a nós, o Abjeccionismo pode ser entendido a partir dos seguintes núcleos orientadores:

1) O ABJECCIONISMO E A LIBERTAÇ̃̃̃. Em sintonia com as associações estabelecidas por Perfecto Cuadrado, Fernando Guimarães e José Augusto Mourão, consideramos fulcral o reconhecimento no Abjeccionismo da constituição de vasos comunicantes mais vastos do que a mera ligação ao Surrealismo, que remontam a uma linhagem patente nas figuras convocadas pelo Surrealismo como precursoras, mas que em muitos casos não foram devidamente conduzidos às mais radicais consequências pelo grupo parisiense. De facto, como defende Édouard Jaguer no Dictionnaire Général du Surréalisme et de ses Environs, as inquietações existenciais que estiveram na origem do Abjeccionismo "font penser à Bataille, à Artaud" (JAGUER, 1982, p. 9). O que nos interessa assinalar é que, se Surrealismo e Abjeccionismo são duas formulações diferentes, pelo menos alguns dos surrealistas portugueses, no essencial da sua obra ou em alguns textos importantes, enveredaram por uma expressão abjeccionista de modo a exprimirem mais adequadamente uma visão absoluta da liberdade como mecanismo de crítica, de sobrevivência e de afirmação pessoal.

\section{2) O ABJECCIONISMO E O INQUÉRITO AO PATRIMÓNIO CULTURAL HUMANO.} O contexto social e político vigente enforma indelevelmente a experiência abjeccionista, embora não esgote a sua problematização, cujo horizonte profundo não é exclusivamente o contexto vivido em Portugal, mas uma discussão da condição humana, em geral, e do estatuto do criador face à ordem social vigente, por outro.

\section{3) O ABJeCCIONISMO E O EIDOS do SURREALISMO PORTUGUES. Desse} modo, aproximamo-nos do entendimento de Fernando Cabral Martins, que defende a possibilidade de considerar-se uma certa plasticidade e fluidez do Surrealismo português, conferindo-lhe a feição de "um termo vago, que se afirma como modo de vida e de revolta além de forma de arte", um "Surrealismo sem fronteiras". Consideramos, contudo, que o 
"eidos surrealista" a que Cabral Martins se refere para descrever a diferença entre momentos específicos do devir surrealista português, passíveis de serem datados, e uma transversalidade "que atravessa a arte moderna portuguesa" (MARTINS, 2016, p. 30-31) poderia designar-se, mais propriamente, como um "eidos abjeccionista", situado ao nível de uma consciência profunda de um tipo de produção de conhecimento assente de uma crítica transversal, que inclui os próprios resultados a que vai chegando, dando uma importante abertura à pluralidade e à controvérsia.

Essa perspetiva singular é descrita com admirável rigor num texto coletivo de novembro de 1949, "Comunicado pelos Surrealistas", publicado por Mário Cesariny em A Intervenção Surrealista (1966) com o título talvez ainda mais programático de "Final de um Manifesto". Exprimindo a natureza da sua posição no contexto do Movimento Surrealista mundial, os representantes do grupo dissidente português caracterizam a sua postura como "anti-colectivista; anti-estábulo literário e respectivo cortejo de esperanças, crenças e sabores; anti-estética; antimoral (religiosa e a outra)" (PETRUS, 1962, p. 160, sublinhados nossos). É expressiva a primazia que, na transversal recusa de crenças, hipóteses definitivas, princípios com finalidade teleológica ou sistemas de valores gregários, se confere à recusa de uma ação coletiva, que interfere no próprio sentido de grupo (ou anti-grupo) dos signatários.

A evidência de que as diferentes facetas da existência individual ocupam um papel relevante no quadro da afirmação livre do sujeito abre caminho à apologia de uma experiência de libertação total, na qual a "vida particular e pública de cada um dos signatários" é dada como uma espécie de reservatório de episódios que assinala a capacidade de o indivíduo se constituir a partir da dialética estabelecida entre a totalidade das suas manifestações vitais e o mundo no qual elas decorrem, potenciando, por sua vez, novas recriações dessa atividade. Todas as facetas do indivíduo adquirem pertinência exemplar, na medida em que concretizam um ideal poético que não conhece fronteiras e que convoca para o seu labor, na expressão de Fernando Cabral Martins, "vários regimes de surrealismo", não necessariamente relacionados com a matriz fundadora proposta por André Breton (cf. MARTINS, 2018, p. 228).

Em 1949, no manifesto coletivo A Afixação Proibida, o contraponto entre a sociedade e o ideal de poeta defendido pelos surrealistas e 
abjeccionistas portugueses é estabelecido a partir do olhar que a sociedade vigente dirige aos seus dissidentes: “É natural que o Poeta seja, por vezes, acusado de libertino e chamado à responsabilidade por incitar ao crime. Mas é sobremodo contraditório que se sinta relativamente a um criminoso um sentimento de simpatia e um desejo de vingança" (LISBOA, 1995, p. 14).

A presença das conotações associadas ao termo "libertino" é remetida não apenas para o domínio de uma rejeição inexplicável por parte da sociedade, mas também, e sobretudo, para o âmbito da incompreensão face à excepcionalidade do olhar poético. "Incitar ao crime" corresponde à forma trivial de designar todas as perspetivas, manifestações e comportamentos impossíveis de digerir pela ordem dominante e, por isso mesmo, torna-se no emblema por natureza dos indivíduos dissidentes.

No texto Aviso a Tempo por causa do Tempo (1950), de António Maria Lisboa, a atmosfera de conflitualidade para com as múltiplas instâncias de representação do poder conduz à descrição da liberdade do poeta como equidistância crítica, conquistada através da livre aferição de quais as soluções mais adequadas à edificação da sua personalidade. Não é propriamente a proposta de uma tábua rasa cultural, mas antes uma plataforma para que o sujeito criador interaja livremente com os diversos discursos sem se comprometer com qualquer deles, p. "não apoiamos qualquer partido, grupo, directriz política ou ideologia (...) apenas nos resta tomar conhecimento: algumas vezes achar bom outras achar mau" (LISBOA, 1995, p. 53, sublinhados do autor). O estranhamento continuado face aos saberes e às instituições da sua sociedade permite ao sujeito emancipado reconhecer nos valores responsáveis pela manutenção da ordem um "fruto e elemento exacto e necessário da sociedade" (LISBOA, 1995, p. 53) e, ao mesmo tempo, ver-se como alguém deslocado dos imperativos ditados por esses códigos. Deste modo, subentendem-se duas categorias de indivíduos, classificadas em função do grau de obediência às normas vigentes.

Ora, Aviso a Tempo por Causa do Tempo conduz esse contraponto no sentido da proposta abjecionista, anunciando um plano plenamente performativo, aquele no qual o indivíduo esclarecido se procura situar: "sendo individualmente e portanto abjeccionalmente desligados das normas convencionais, temos o máximo regozijo em ver essas mesmas normas nos componentes da sociedade. Assim delas daremos por vezes testemunho e 
mesmo ensino" (LISBOA, 1995, p. 53, sublinhado nosso). Por um lado, o indivíduo repudia os princípios que sustentam a estrutura social, que sujeita ao desprezo inerente à abjeção; por outro lado, os pilares em que assenta a sociedade são entendidos como uma fonte de conhecimento que o indivíduo observa e, ironicamente, utilizará nas suas próprias ações criativas. Uma tal atitude acarreta, contudo, um risco crescente, dado que a recusa dos poderes operativos da sociedade - "a ordem, o trabalho, o progresso, a família, a pátria, o conhecimento estabelecido (religioso, filosófico, científico)" - produz também um estado de marginalização (LISBOA, 1995, p. 54).

A posição assumida pelo indivíduo abjeccionista, tão próxima das leis da Natureza quanto é possível à consciência do animal pensante que é o Homem, permite-lhe fugir ao mimetismo cultural para encontrar os próprios procedimentos com que vai questionando a realidade. Não sendo de forma alguma estanque, a interação do indivíduo com o seu universo de sentido corresponde a uma ambição de conhecimento que interfere nos próprios dados computados:

Conhecer é a um tempo receber e dar, é não só saber que algo se processa de certa forma, mas provocar alteração no processo e no que se processa, de que também faz parte. Conhecer é receber a realidade tal qual vem e no mesmo tempo torná-la outra realidade, de forma que a realidade não venha sem ser indo. Sem dúvida que é em oposição à tradicional forma de conhecimento que nos situamos. (LISBOA, 1995, p. 101)

O Abjecionismo exprime-se, em António Maria Lisboa, de acordo com o desdobramento desta última evidência: a de que o indivíduo deve participar, a partir da sua compreensão pessoal do mundo e dos processos a que recorre para se exprimir, no desenvolvimento infinito do mundo humano, à margem dos procedimentos tradicionais, que passam pela imposição de uma via exclusiva para o acesso à verdade. A atuação do indivíduo no real, apontando necessariamente para a autonomia distintiva da sua visão peculiar das coisas, corresponde tanto a um impulso íntimo para a permanente mobilidade física e espiritual como para a projeção de si através de uma nova via. Estão, desse modo, conjugadas as duas necessidades homeostáticas do ser humano, a distinção face ao contexto originário e aos outros organismos e a construção de um projeto 
suficientemente singular para que o mundo do sujeito possa perdurar no tempo.

É neste sentido que devem situar-se algumas afirmações desenvolvidas na conferência-manifesto "Erro Próprio" (1952), que serão retomadas por Mário Cesariny e por Luiz Pacheco. Ao convidar o público deste manifesto-conferência a deslocar os horizontes em que se move o ser humano do plano da "chamada vida prática" para um outro patamar de conhecimento, aberto a novos horizontes, Lisboa deixa também claro que essa via alternativa implica uma de três coisas: 1) o permanente ímpeto questionador, através do qual o indivíduo se permite confrontar-se com o seu contexto e sujeitá-lo a crítica; 2) um hipotético estado de desespero, relacionado com uma possível experiência da aparente falta de sentido para a existência, sobretudo quando sujeita a condicionamentos de ordem sociopolítica; e 3) uma aguda afirmação da própria identidade, "contra toda a espécie de influências estranhas e dirigidas contra os nossos desejos e vontade", dado que "cada uma das nossas atitudes é uma resposta aos problemas da nossa própria vida" (LISBOA, 1995, p. 26).

Assim, e em conformidade com algumas ideias fundamentais de Pedro Oom, como veremos, o individualismo abjecionista germina da confluência entre a dúvida, a consciência de um desencontro permanente face à realidade estabilizada e a afirmação de si em concordância exclusiva com as próprias necessidades. $\mathrm{O}$ caminho individual corresponde à instauração da autocrítica no desenvolvimento de um percurso que confronta o indivíduo concreto com a idealização que vai fazendo de si próprio. Dado que nenhuma via é mais adequada do que qualquer outra, na medida em que corresponde à pura manifestação de uma existência, a proposta libertadora na qual se inscreve o Abjecionismo implica o reconhecimento das limitações humanas - o "erro próprio" que cada indivíduo se revela ao ser analisado pelos seus próprios padrões - e, ao mesmo tempo, a disponibilidade para converter essas limitações em fontes de experiência e de conhecimento.

Para a devida compreensão da proposta de António Maria Lisboa, deve ser tido em conta o contraste proposto por Breton, Bataille e Artaud entre o sentido tradicional de liberdade e a libertação. A libertação, coincidindo com o acesso a um estado de experimentação existencial, é lida, nesta perspetiva, como sinónimo do devir imprevisível do sujeito e, 
nessa medida, está sempre dependente de cada nova etapa do percurso individual.

A demarcação individual, que converte o indivíduo no seu único e fundamental centro operativo, é contrária ao peso impositivo que tende a alimentar os projetos universalizantes dos saberes desenvolvidos pelas comunidades humanas.

É a crítica simultânea ao paradigma derivado das Luzes e à sua integração no ideal historicista de matriz hegeliana, cuja estreiteza uniformizadora procurou isolar o indivíduo da única realidade existente, a do seu contacto direto com o exterior natural e social, que estrutura a visão de António Maria Lisboa: "Apenas os que gostam de medir os passos pela experiência dos outros e à Luz Fria duma Razão Qualquer (há tantas!), ou fazer medir os outros pela sua, apregoam a «histórica» experiência quando a História não é mais do que o pior caminho! A existência não se pensa, pois o Imprevisto enche-a (LISBOA, 1995, p. 29).

"Erro Próprio" expõe os pressupostos fundamentais da leitura abjecionista do alcance profundo das conquistas derivadas do Surrealismo. Para António Maria Lisboa, a dinâmica surrealista definia, acima de tudo, uma reação particular aos desafios e exigências colocados ao ser humano independente por uma determinada definição dos conteúdos da Modernidade. Com efeito, é das escolhas predominantes de uma linha de desenvolvimento do paradigma intelectual do Ocidente que decorrem as condições necessárias para que o ser humano se tenha deixado encarcerar no que parece ser uma réplica da caverna alegórica de Platão, marcada pela repetição determinista dos mesmos hábitos e pela abdicação do que de genuíno distingue cada indivíduo dos demais: "O Homem move-se numa redoma fechada, sem oportunidades, não sabendo o que existe para além do vidro baço que o limita" (LISBOA, 1995, p. 33).

Longe de ser um ato isolado no decurso da revolta do indivíduo contra o mundo que o oprime, o Surrealismo é uma formulação possível, escolhida precisamente por permitir a cada indivíduo responder da forma mais adequada aos seus próprios imperativos pessoais. Em carta a Cesariny, António Maria Lisboa propõe que o Surrealismo seja entendido como uma Surrealidade, superando as limitações e fragmentarismos típicos dos grupos parisienses para coincidir com uma luta intransigente e agressiva patente nos primeiros momentos do movimento e que coincide com a procura permanente de um estado de libertação. 
Nessa leitura, o Surrealismo deixa de ser a designação de um determinado movimento, do modo como esse movimento se exprimiu na sua génese o termo, passando a ser uma forma de conceber o movimento do organismo individual no decurso da sua aventura:

A grande força do Surrealismo, força e vitalidade, consiste na sua capacidade de movimento, não de adaptação, mas, sob qualquer aspecto aparente, transformador. E a sua veracidade e resultado depende (sic) somente da posição interior que, individualmente, cada um vai tomando, ou tendo, e necessariamente pondo em prática". (LISBOA, 1995, p. 39)

António Maria Lisboa define o escopo do Abjecionismo em função desta potência permanente da Surrealidade, fazendo confluir na proposta abjecionista um ponto de vista sobre a liberdade, uma apologia do individualismo absoluto que se contrapõe à comunidade e uma teoria mais ampla do imperativo de qualquer sujeito criador empenhado num processo de edificação transformadora:

Uma mudança de rumo em TODOS e em TUDO não pode deixar de começar em nós individualmente. "Até que ponto pode chegar um homem desesperado quando o ar é um vómito e nós seres abjectos?» frase que poderemos intitular de central. E esta posição de abjecção, de desespero irresignável, leva-nos à única posição válida: SOBREVIVER, mas Sobreviver LIVRES, pois não existe sobrevivência na escravatura, mas na não aceitação desta. «Ser Livre» é possuir-se a capacidade de lutar contra as forças que nos contrariam, é não colaborar com elas. (LISBOA, 1995, p. 34)

Esse projeto é situado por António Maria Lisboa numa profunda centralidade atribuída à Crítica, verdadeiro centro operativo do seu vocabulário:

A crítica, para nós, é a acção AGRESSIVA dum indivíduo que se opõe e contrapõe a outro (...). O Homem só se apresenta válido socialmente quando se afirma em combate a outro, que, em primeira e última análise, é sempre possuidor, como o primeiro, duma «experiência decisiva», «uma experiência de suicídio» que lhe dá bagagem para se afirmar igualmente. (LISBOA, 1995, p. 40) 
A Crítica, conforme proposta por António Maria Lisboa, situa-se ao nível de uma reação persistente aos valores consagrados, visando esvaziar sistematicamente os conteúdos que validam as várias ficções canonizadas: “Todos estes exemplos chegam para mostrar que a «vida» possui o dom irresistível de pôr os homens perante a contradição e de os exasperar" (LISBOA, 1995, p. 41).

Ora, é precisamente nesse ponto entre a Contradição e o Desespero que evolui toda a ação libertina do Abjecionismo. Conforme esclarece numa carta dirigida a Henrique Risques-Pereira, o ponto de vista abjecionista preconizado por Lisboa não admite a pacificação idealista reconhecida em certas manifestações da dialética hegeliana no movimento surrealista, mas um percurso incessante que parte do já adquirido para novas formas de recusa dos atavismos existentes e de conquista de novos horizontes criadores. É ao abrigo desse exercício renovador que se prepara uma ampla "destruição dos mitos" e a consequente necessidade de "agir sobre os outros objectos criticamente", transformando-os: "a Crítica, que é a nossa forma de permanência, a Crítica Agressiva toma todas as formas imaginárias, impossíveis mesmo por excelência, realizadas desde que destrua, abale, incite, ame!)" (LISBOA, 1995, p. 304).

Se a mundividência dominante produziu uma série de visões de mundo gradualmente ultrapassadas, e cuja alternância explicita a realidade profunda da consciência humana, voltada para a diluição dos vocabulários consagrados por outros que se impõem para conquistarem por sua vez a supremacia ideológica, cabe ao indivíduo despertar para o seu próprio papel singular em todo esse processo e renegar a regra subjacente ao labor com que a doxa se faz e refaz para prevalecer.

É essa noção que se encontra exemplarmente sintetizada na frase de Paracelso escolhida como epígrafe de "Erro Próprio": "Não são os olhos que fazem ver ao Homem mas ao contrário o Homem que faz com que os olhos vejam" (LISBOA, 1995, p. 23). A independência perceptiva é devolvida ao seu estado natural, respondendo aos problemas suscitados pela realidade a partir de uma organização singular dos dados recolhidos. Assim, o conhecimento obtido no confronto com a realidade depende, acima de tudo, do confronto direto do próprio intelecto com os objetos naturais e artificiais partilhados por todos. É a partir desse processo que se produz a crítica e, com ela, a transformação do experienciado numa forma 
privada de edificação do indivíduo que lhe oferece um sentido, o da sua experiência vital.

Conclusões semelhantes podem encontrar-se numa importante entrevista de Pedro Oom ao Jornal de Letras e Artes em 1963, na qual clarifica o sentido do Abjecionismo e a sua dinâmica específica. Esse documento é essencial para a consolidação de um discurso que assume como principal pilar a noção de que a liberdade do sujeito criador, nas suas várias facetas, não se revolta contra um discurso específico, no qual se concentram todos os seus esforços, mas na própria estrutura que faz corresponder os hábitos sociais de estabilização à anulação das aporias.

Substituindo em parte um manifesto que Pedro Oom teria produzido na década de 40 e que se teria perdido, a entrevista recupera os fundamentos do metadiscurso abjecionista do qual António Maria Lisboa, considerado a par de Oom um dos progenitores dessa via, acabou por ser o mais efetivo expositor. Importa ter em conta que essa entrevista se situa entre duas fases do percurso do Abjecionismo, dando contornos mais amplos às ideias defendidas anteriormente, num novo ambiente intelectual, no qual os grupos surrealistas inaugurais haviam dado lugar à dispersão de propósitos e coletivos muito heterogéneos. Transmitidas num momento charneira, as propostas de Pedro Oom contribuem para estabelecer a medida do contraponto que terá as principais repercussões na dualidade representada, desde 1963, pelas propostas de Mário Cesariny - delineando uma espécie de convivência entre autores e escolas muito diversas, através da concepção surreal-abjecionista - e de Luiz Pacheco que introduz publicamente a sua proposta neoabjecionista, apropriandose da verve radicalmente polémica do Abjecionismo para o universo da sua libertinagem.

Diferindo dos processos tanto de um como do outro, Oom procura acentuar o lugar exato da ambivalência tipicamente abjecionista. A sua tonalidade permite, também, evidenciar os motivos que haviam contribuído para adensar a abjeção experienciada, depois do desaparecimento do ímpeto resistente de António Maria Lisboa:

As experiências a que procedemos há mais de dez anos são hoje continuadas por outros, talvez até com maior vigor e consciência (...). Acontece, porém, que a realidade social de hoje, menos «feroz» que há dez anos, mas muito mais dissolvente, tem dulcificado os ímpetos mais «agressivos». (apud CESARINY, 1997, p. 294-295) 
O Abjecionismo é apresentado por Pedro Oom como uma atitude, uma forma de o indivíduo evoluir adequadamente face a um contexto que procura submetê-lo aos padrões morais e espirituais da sociedade moderna e da civilização por esta promovida. A dúvida expressa por António Maria Lisboa é retomada enquanto síntese elementar de uma posição comum desenvolvida "na resposta que cada um dará à pergunta: «que pode fazer um homem desesperado quando o ar é um vómito e nós seres abjectos» (apud CESARINY, 1997, p. 291).

Para Pedro Oom, a génese da distinção entre Surrealismo e Abjecionismo encontra-se na recusa de um estado de pacificação cultural capaz de anular perspetivas contrapontísticas:

A diferença fundamental entre surrealismo e abjeccionismo está no seguinte: nós também acreditamos na existência de um determinado ponto do espírito onde a vida e a morte, o alto e o baixo, o sonho e a vigília, etc., deixam de ser contraditoriamente apercebidos, mas cremos igualmente na existência de um outro ponto do espírito onde, simultaneamente à resolução das antinomias se toma consciência das forças em germe que irão criar novos antagonismos. Em resumo, Breton diz que há um ponto do espírito onde as antinomias deixam de ser contraditoriamente apercebidas e eu digo que, mesmo idealmente, duas proposições antagónicas não se podem fundir sem que logo nasça uma proposição contrária a essa síntese. Por isso, tanto a posição surrealista como a contrária me parecem limitadas. (apud CESARINY, 1997, p. 292)

Parecendo um aspecto de pormenor, o contraste apresentado por Pedro Oom encontra-se diretamente relacionado com a irredutibilidade da crítica abjecionista.

$\mathrm{Na}$ perspetiva de André Breton, que atribui ao movimento surrealista uma finalidade, um propósito e uma teleologia, existiria um momento definitivo relativamente ao qual poderia falar-se de uma espécie de fim da História, dado que se conciliariam definitivamente as múltiplas facetas do real, finalmente pacificadas. Lido em função dessa tese de André Breton, defendida no Segundo Manifesto do Surrealismo (1929) e de algum modo corrigida pelo próprio em textos posteriores, o movimento surrealista tenderia a aproximar-se, embora a coberto de uma certa vertigem suprarrenal, de outras doutrinas assentes na crença num efetivo 
progresso do ser humano. Tanto o Homem como o mundo por este habitado poderiam ser transformáveis tendo em vista um desfecho absoluto, no qual os pontos de vista contraditórios tenderiam a deixar de fazer sentido.

A correção operada por Pedro Oom corresponde a um estado de exaltação da liberdade do pensamento, apontando para a problematização dos dados que num determinado momento foram tidos como seguros. A crítica aos mitos consagrados a que o Surrealismo começou por corresponder, encontram-se, nesta medida, perfeitamente alinhados com a plena compreensão dos limites do conhecimento humano, divergindo do otimismo epistemológico com que Breton adaptava os ideais historicista e iluminista ao discurso específico da surrealidade. Existe assim no discurso abjecionista um alerta para o inevitável germinar de novas problemáticas, questionamentos e controvérsias, num horizonte humano aparentemente inesgotável, ao qual pertence o próprio ponto de vista bretoniano, relativamente ao qual podem por isso ocorrer divergências críticas. Dada a evolução das ideias, e desse modo a possibilidade de ocorrer uma certa esclerose dos propósitos surrealistas e o germinar de novos paradigmas mais adequados às futuras necessidades do ser humano, a proposta abjeccionista acentua a necessidade de resistência permanente aos vários vocabulários em cisão.

Face a um contexto no qual "o ar é um vómito e nós seres abjectos", as respostas à pergunta "que pode fazer um homem" - e acentue-se que o foco se encontra na singularidade, pois é de "um homem" e não "do Homem" que se está a falar - podem ser tantas quantos os sujeitos capazes de se libertarem, afirmando-se. Nessa medida, a formulação de Pedro Oom permite colocar a questão do ser humano num plano mais vasto do que o relacionado com o contexto português diretamente implicado na definição do Abjecionismo, na medida em que parece constituir uma súmula não só da condição histórica e poética das vanguardas portuguesas, como sugere Fernando Cabral Martins (MARTINS, 2016, p. 28), mas também da própria condição humana. Com efeito, se entendermos que "um homem desesperado" é uma descrição apropriada do indivíduo que ganhou consciência das suas contingências e limitações, sejam quais forem os seus contextos específicos, o entendimento dos seres humanos como "seres abjectos" ultrapassa a crítica a um enquadramento sociopolítico marcante - aquele que faz do ar "um vómito" - para apontar para uma perspetiva 
lúcida a respeito da íntima natureza humana. O plano das ideologias contribui, apenas, para adensar esse panorama, impondo uma negação da realidade intrínseca da condição humana.

É tendo como pano de fundo as propostas e esclarecimentos de António Maria Lisboa e de Pedro Oom que passaremos a considerar a controvérsia mantida por Mário Cesariny e Luiz Pacheco, essenciais para a consolidação do discurso abjecionista no panorama geral da metapoética do Surrealismo português. Com efeito, se Cesariny terá sido a voz mais crítica do Abjecionismo, ou pelo menos das tentativas de o associar ao Surrealismo ou de o ver como uma manifestação portuguesa deste, é paradoxalmente na sua ação historiográfica e crítica que mais se proporcionou o reconhecimento público do assunto, com a plasticidade histórica e geográfica de que hoje se pode falar.

A presença da abjeção no modo como Cesariny se dirige à realidade portuguesa e aos diferentes percursos seguidos na sequência da aventura surrealista coletiva encontra-se expressa em algumas cartas dirigidas a Cruzeiro Seixas, em 1953. É através da inquietação abjecionista que classifica as experiências de poetas associados a Os Surrealistas que haviam seguido caminhos coincidentes com a doxa, casos de Risques Pereira e de Carlos Eurico da Costa, e lhes contrapõe uma outra atmosfera derivada de uma irredutibilidade inspirada nas propostas de António Maria Lisboa e de Pedro Oom. Para exemplificar essa toada, Cesariny não esquece o caso emblemático de Luiz Pacheco, cuja ação, até ao momento da ruptura entre ambos, se foi desenvolvendo em estreita ligação.

Em janeiro de 1953, Cesariny mostra-se particularmente afetado pelos "vómitos a que vamos chegando todos", recuperando parcialmente os termos utilizados por Pedro Oom e António Maria Lisboa ao cunharem a pergunta fundamental do Abjecionismo. É, de resto, a ambígua inquietude abjecionista, entre a aproximação a estados de renúncia e a necessidade de afirmação alternativa, que se encontra patente na descrição do quadro em que ainda se movimentavam os poetas surrealistas portugueses, entre a "vida-esperança-desespero" de Risques Pereira e de Pedro Oom e a "inapetência para ser feliz" que Cesariny se atribui (CESARINY, 2014, p. 77-78). Ora, essa disposição não é entendida como característica exclusiva, mas como uma espécie de sensibilidade comum, próxima da dos que se haviam parcialmente distanciado do idealismo surrealista. Luiz Pacheco é reconhecido como uma das mais exemplares 
figuras dessa condição, uma espécie de caso extremo: “É o preço, é o preço! Eis o que impõe à minha consideração, apesar dos dislates, o Luiz Pacheco. Eis aí outro louco também não ocupado com as felicidades..." (CESARINY, 2014, p. 85-86).

Importa lembrar que Cesariny havia sido diretamente associado ao Abjecionismo por António Maria Lisboa, pouco tempo antes destas cartas: "Não se tratava em mim (em nós) de negar o Surrealismo e os seus princípios, mas ilibava-me eu de tomar lugar na querela do eu sou, tu não és. Serei ou não surrealista de hoje para o futuro com a minha Metaciência e o Nosso Abjeccionismo - eu não me pronunciarei sobre tal" (LISBOA, 1995, p. 196).

Ao expor a sua atitude através de duas disposições próprias da poética abjecionista - o individualismo metacientífico, que recusa depender de qualquer outro movimento ou grupo, e "o nosso Abjecionismo" - Lisboa mostrava-se mais próximo de aceitar a interrogação abjecionista do que propriamente conformado com uma visão estanque do Surrealismo. Ao mesmo tempo, implicava Cesariny na toada abjecionista, pelo menos em termos de atividades coletivas, embora a expressão pareça indiciar que o Abjecionismo corresponde à forma fundamental de compreender a forma portuguesa de se ser surrealista.

O texto Autoridade e Liberdade São Uma e a Mesma Coisa (1958), de Cesariny, é o mais representativo desse influxo abjecionista na sua obra. Com efeito, e se considerarmos a carta de António Maria Lisboa como o palco de uma afirmação de liberdade individual e coletiva, o facto de Cesariny convocar para este texto uma das frases que António Maria Lisboa dá a conhecer nessa carta estabelece nexos fundamentais entre os dois documentos.

Com efeito, António Maria Lisboa reage ao relativo fracasso das atividades dos surrealistas portugueses com a apologia de um percurso individualista alternativo, no qual "é a acção verdadeiramente livre e que não precisa nem de informadores nem de polícias" a caracterizar a totalidade das pesquisas empreendidas (LISBOA, 1995, p. 194). Introduzido esse distanciamento, e aberto o caminho para a circunscrição de todos os seus esforços à Metaciência e ao Abjecionismo, Lisboa dedicase a definir os princípios da pesquisa metacientífica, relacionados, em grande medida, com a situação do Poeta na comunidade e, sobretudo, com um novo entendimento da condição humana, em virtude do qual o 
indivíduo se retira da mera biologia para adquirir uma dimensão criadora. Um desses princípios relaciona-se com uma nova visão da temporalidade, avessa ao estreitamento dos pressupostos tradicionais, como expresso no texto "Certos Outros Sinais": "à «fixação da realidade» prefere-se uma cada vez mais funda e vertiginosa (...) conquista do conhecimento do homem que o mesmo é dizer do Universo (...). E ao caminharmos para o Futuro é o Passado que conquistamos" (LISBOA, 1995, p. 111-112).

Ora, no texto de Mário Cesariny, esta frase é recuperada para definir o grau de oposição do poeta a uma concepção tradicional da História: “Dir-me-eis: isto é história passada. Dir-vos-ei: parece-vos. Dirme-eis: então? Dir-vos-ei: tenho um amigo que me garantiu que ao caminharmos para o futuro é o passado que conquistamos" (CESARINY, 2015, p. 83).

No âmbito dos procedimentos adequados à conquista da liberdade possível nesse panorama pleno de fragmentarismos, Cesariny descreve as seguintes opções: "Na hipótese de estar sendo, o fragmento de liberdade será um Organicismo (prof. Geraldes Barba)? Uma Inorgânica Superior (António Maria Lisboa)? Um Abjeccionismo (Pedro Oom)? Edições sim mas das baratas (Mário Henrique Leiria)?" (CESARINY, 2015, p. 83-84).

É tendo por base a ideia de que um contexto determinado pode dar origem a diferentes manifestações individuais que Cesariny estabelece a distinção entre dois sentidos de autoridade, presentes na proposta de António Maria Lisboa e na tese fundamental do Abjecionismo: por um lado, a autoridade corresponde às várias instituições destinadas a impor uma ordem rígida, de acordo com a qual ocorre uma fixação ininterrupta do real; por outro lado, a autoridade situa-se no plano do indivíduo que se autonomiza e reconhece nas suas faculdades particulares o ponto de partida para uma genuína gesta criativa. A autoridade definida por Cesariny, equivalendo ao desejo de começar um movimento libertador a partir do indivíduo e da sua capacidade de resistir autonomamente ao contexto fragmentário no qual se encontra inserido, inscreve-se diretamente numa proclamação intransigente, afim da fórmula base do Abjecionismo:

Ser-se livre é possuir-se a capacidade de lutar contra o que nos oprime. Quanto mais perseguido mais perigoso. Quanto mais livre mais capaz. Do cadáver dum homem que morre livre pode sair acentuado mau cheiro - nunca sairá um escravo. 
Autoridade e liberdade são uma e a mesma coisa. (CESARINY, 2015, p. 85)

Assim, e tendo em conta inclusive a inscrição da derradeira manifestação de liberdade num elemento diretamente relacionado com a área semântica da abjeção - o cadáver como resíduo definitivo do sujeito resistente -, a conexão agressiva que Cesariny propõe entre o autor e as suas múltiplas afirmações é uma variante possível do mote abjecionista. Adquirindo na resistência às múltiplas perseguições a capacidade de se manter livre, pela exploração plena da sua autoridade pessoal, o indivíduo confrontado com um ambiente fragmentário - o ar que é um vómito responde de acordo com as suas propensões particulares e, desse modo, nunca poderá considerar-se um escravo.

A partir da década de 60, a intervenção de Cesariny, no que concerne ao modo como o Abjecionismo adquiriu visibilidade pública, está acima de tudo relacionada com a fixação historiográfica do termo, das suas principais teses e das polémicas que dele sobressaem. A perspetiva do Abjecionismo defendida por Cesariny desenvolve-se, no essencial, de acordo com três ângulos de leitura distintos. Primeiro, a deriva abjecionista é encarada como designação possível de práticas, experiências e obras nas quais a atitude agressiva relativamente aos valores vigentes é particularmente vigorosa, conforme expresso na antologia por si organizada Surreal-Abjeccion (ismo) (1963); depois, em algumas ocasiões particulares, é-lhe conferindo o estatuto de faceta do Surrealismo em Portugal, orquestrada por Pedro Oom; finalmente, sobretudo nos casos mais polémicos, o Abjecionismo é encarado como desvio aos propósitos surrealistas, seguido, fundamentalmente, por elementos pertencentes ao grupo do Café Gelo, dominados por uma ótica niilista e suicidária, e, mais particularmente, por Luiz Pacheco.

Quanto à antologia Surreal-Abjeccion (ismo) (1963), importa salientar que os seus propósitos passavam, em grande medida, por abranger as mais diversas fontes de reação à sociedade vigente, contribuindo para o influxo de processos próprios do Surrealismo no território mais adequado ao discurso programático neorrealista.

O subtítulo da antologia acentua que esta se encontra "de acordo com o propósito inicial", que, dada a autoridade do antologiador, só pode ser entendido como aquele que motivou o seu percurso conquistado na transição do Neorrealismo para o Surrealismo, primeiro, e da 
impossibilidade de Surrealismo para uma toada ambivalente na qual cabe a presença do Abjecionismo e, sobretudo, dos criadores abjecionados pelo sistema dominante. $\mathrm{O}$ "propósito inicial" permanece aquele descrito em Autoridade e Liberdade São Uma e a Mesma Coisa - a conquista da liberdade pela afirmação de uma autoridade ou, neste caso, de várias autoridades conjugadas de uma forma pouco ortodoxa, pois não existe nenhum elo comum particularmente evidente além da própria necessidade de denunciar uma circunstância.

Se, no conteúdo da segunda antologia de Cesariny, A Intervenção Surrealista (1966), Pacheco não encontra traços "da passagem duns tipinhos do neo-realismo para o surrealismo e deste para o abjeccionismo", é precisamente esse roteiro que se encontra delineado em Surreal-Abjeccion (ismo). Nessa antologia, é também conferido um destaque indiscutível ao mote de Pedro Oom e ao contraponto que este representa relativamente aos ideais de André Breton, na medida em que as frases fortes do contraponto entre os dois são dadas como epígrafes do conjunto:

Tudo leva a crer que existe um certo ponto do espírito de onde a vida e a morte, o real e o imaginário, o passado e o futuro, o comunicável e o incomunicável, o que está em cima e o que está em baixo deixam de ser apercebidos contraditòriamente.

Tudo leva a crer que existe um certo ponto do espírito de onde a vida e a morte, o real e o imaginário, o passado e o futuro, o comunicável e o incomunicável, o que está em cima e o que está em baixo deixam de ser e não deixam de ser apercebidos contraditoriamente. (CESARINY, 1963, p. 13)

As consequências da aparentemente simples mas bastante significativa diferença entre os dois manifestos de intenções são explicadas com clareza por Pedro Oom na referida entrevista ao Jornal de Letras e Artes, no mesmo ano da antologia:

A diferença fundamental entre surrealismo e abjeccionismo está no seguinte: nós também acreditamos na existência de um determinado ponto do espírito onde a vida e a morte, o alto e o baixo, o sonho e a vigília, etc., deixam de ser contraditoriamente apercebidos, mas cremos igualmente na existência de um outro ponto do espírito onde, simultaneamente à resolução das antinomias se toma consciência das forças em germe que irão criar novos antagonismos. Em resumo, Breton 
diz que há um ponto do espírito onde as antinomias deixam de ser contraditoriamente apercebidas e eu digo que, mesmo idealmente, duas proposições antagónicas não se podem fundir sem que logo nasça uma proposição contrária a essa síntese. (apud CESARINY, 1997, p. 293)

É este o panorama do Abjecionismo que Mário Cesariny transmite em 1963. Nos anos subsequentes, contudo, o seu ponto de vista vai conhecer transformações significativas, entre a tentativa de circunscrever esse ponto de vista a Pedro Oom e a desvalorização ou mesmo recusa do Abjecionismo.

Em 1966, ao procurar expor os principais momentos do percurso do Surrealismo em Portugal, na obra A Intervenção Surrealista, Mário Cesariny centra o pendor abjecionista em Pedro Oom:

Pedro Oom: poemas de $O$ Homem Bisado, com versos susceptíveis de serem intercalados uns pelos outros mudando a sua posição no poema sem que este perca a vibração poética. Escreve um manifesto «abjeccionista» que entretanto se perdeu (como a quase totalidade dos seus poemas desta época). Compõe, dentro do mesmo espírito, um baralho de cartas onde estão escritos versos, ou expressões poéticas, cuja leitura é susceptível de ordenar o futuro imediato (...). Da sua intensa actividade poética nesta época e dos textos chegados até hoje restam os poemas «O Sonhador Espacializado», «Um Ontem Cão», os poemas de A Afixação Proibida e alguns, escassos, inéditos. No entanto, muitas das mais importantes posições assumidas por António Maria Lisboa no manifesto «Erro Próprio» resultam do convívio com Pedro Oom. (CESARINY, 1997, p. 62)

A centralidade de Afixação Proibida (1949) e de "Erro Próprio" (1950) no panorama metadiscursivo do Surrealismo português seria suficiente para atribuir ao Abjecionismo um lugar cimeiro na visão que Cesariny tinha do que poderia considerar-se uma genuína intervenção surrealista. Mas a presença do Abjecionismo em A Intervenção Surrealista não se esgota no diálogo fundamental entre Lisboa e Oom. São várias as passagens da obra em que o termo, de forma mais ou menos explícita, é assinalado, e nas suas várias variantes.

Apesar de o ângulo de interpretação se alterar, relativamente à antologia de 1963, através de um confinamento em episódios específicos dos grupos surrealistas e ao seu diálogo com a tradição surrealista internacional e com o ambiente contemporâneo, o Abjecionismo é 
escolhido como uma das etapas possíveis de um percurso ou, mais propriamente, na economia geral da obra, a etapa definitiva, na medida em que os textos que concluem o volume têm como eixo a deriva abjecionista.

O testemunho de Virgílio Martinho, por exemplo, dá a ver a diversidade dos usos possíveis do Abjecionismo e da terminologia a este associada. Para Martinho, os que haviam contactado com o movimento nas suas primeiras manifestações públicas poderiam ser descritos, na sua maioria como "público abjeccionista do Surrealismo" (apud CESARINY, 1997, p. 263). Essa formulação remete para o mesmo panorama identificado por Pedro Oom no momento em que fixou a interrogação central do Abjecionismo: é a sociedade, ao nível da incapacidade intelectual que a impede de acompanhar adequadamente a proposta inovadora dos surrealistas, que merece ser considerada abjecionista. A abjeção é, assim, um sintoma eficaz do modo como a doxa funciona sempre que depara com perspetivas contrárias à estagnação cultural por ela promovida. Martinho exprime precisamente essa questão ao associar os valores "da Arte, da Moral e do Respeito" à ação desestabilizadora dos "estudantes mussolinistas" e ao perfil "marialva" dos que perturbaram as sessões surrealistas na Casa do Alentejo, em 1949 (apud CESARINY, 1997, p. 263269). É, pois, em clave Surrealista que Cesariny opta por ajustar contas com a sociedade portuguesa que perturbara os primórdios da sua atividade como surrealista.

Apesar das reservas, os laços entre Surrealismo e Abjecionismo, por intermédio de Pedro Oom, são ainda sustentadas pelo próprio Cesariny num texto com repercussão internacional, Para uma Cronologia do Surrealismo Português, que, longe de excluir o Abjecionismo, lhe confere o estatuto de uma das suas três manifestações peculiares: “o «Amor, Mágico e Extra-Mundo», de António Maria Lisboa; o «Amor, Amor Humano», amor que «nos devolve tudo o que perdêssemos», de Mário Cesariny de Vasconcelos; e "a impossibilidade de Amor, ou a Abjecção, de Pedro Oom" (CESARINY, 2015, p. 272).

Em 1974, contudo, Cesariny opta por desligar abruptamente o Surrealismo e o Abjecionismo, relacionando a eventual aproximação estabelecida entre eles na antologia de 1963 com o contexto epocal e com o que, no seu entender, seria um território híbrido e irrepetível, devido exclusivamente a problemas circunstanciais e não a qualquer ideário comum ou contaminação possível de propósitos: 
Por precaridade de situação mesológica fiz reimprimir na colectânea não-surrealista nem-abjeccionista mas sim grafada «SurrealAbjéccion» (o «ismo» em muitíssimo mais pequeno, coisa que, parece, não convenceu ninguém, o que foi e é pena pois aqui e agora e sempre em todo o lado o surrealismo não tem nada a ver com o abjeccionismo ou só terão de comum o haverem-se conhecido na cadeia, onde vai tanta gente por tão diversos cantares e até só por receio, visita de estudo e turismo. (CESARINY, 1995, p. 239)

Esta afirmação encontra-se diretamente relacionada com Luiz Pacheco e com a derradeira etapa da disputa entre ambos, o diálogo editorial representado por Pacheco versus Cesariny e O Jornal do Gato. Cesariny opta por introduzir na sua reação uma carta datada de 15 de setembro de 1959, na qual Pacheco situa a sua presença no percurso do Surrealismo português, afastando-se do discurso surrealista propriamente dito para encontrar no Abjecionismo uma alternativa que permitiria, de acordo com o espírito da antologia de 1963, aproximar projetos muito diversos:

Em relação ao surrealismo português, não fui mais que um sacristão, um apaniguado de terceira. Quanto ao abjeccionismo, aí todos nós temos um lugar reservado, de destaque (...) Mas o título essencialmente está certo. Precisamente, a nossa geração, e outras mais que vieram (antes e depois), somos todos da abjecção pura. O que nada tem a ver com a moralidade de cada um, mas apenas com o ar que todos respiram. (CESARINY, 1974, p. 20-21)

A análise de Luiz Pacheco resume em breves linhas a riqueza da antologia. No momento singular representado por Surreal-Abjeccion (ismo), o que ocorre é um extravasamento do Surrealismo enquanto movimento doutrinário historicamente localizado, que permite que indivíduos que não se reconhecem como surrealistas possam ter ali o seu espaço de manifestação pessoal. A formulação icónica de Oom é duplamente citada, evidenciando a total compreensão de Pacheco relativamente a um dos seus sentidos potenciais. A uma condição comum - o ar-vómito que a todos envolvia - poderiam corresponder diferentes "moralidades" - aquilo que cada um poderia, nessas circunstâncias, fazer para se opor a elas.

A reação de Cesariny passa por referir o texto dedicado a Buñuel e por desenvolver deste modo o que ficara nele implícito, evidenciando que, 
neste momento, o Abjecionismo estaria de tal modo conotado com Luiz Pacheco que as próprias afirmações de António Maria Lisboa ou de Pedro Oom precisavam de ser extraídas ao ambiente geral abjecionista em que Pacheco mergulhara:

O ar respirado por António Maria Lisboa é sem intermediários e altamente destrutor do ar absorvido por Luiz Pacheco em terceira ou quarta narina, enquanto o aparelho respiratório de Pedro Oom não o deixou sobreviver a uma rajada de ar puro. (...) A abjecção promovida por condições sócio-políticas será a única a explicar a vagabundagem do poeta? Sabemos que não. Artaud fugiu espavorido da democracia francesa dos anos trinta. Mayakowsky suicidou-se em plena gesta do comunismo russo. A estes dificilmente se poderá contar o conto do abjeccionismo nos termos em que, sempre contrário ao surrealismo, faz ditosa carreira em Portugal. (CESARINY, 1974, p. 20-21)

A derradeira imagem que Cesariny deixa do Abjecionismo, pelo menos na sua existência portuguesa, isola Luiz Pacheco dos representantes das etapas anteriores, procurando evidenciar, por um lado, que a experiência da abjeção não se deve a contextos históricos precisos, e, por outro, que o Abjecionismo acabara por se converter numa narrativa apropriada pelos interesses de quem não poderia de modo algum encontrar-se ao nível das exigências do Surrealismo a que haviam pertencido Lisboa e Oom. De facto, Cesariny dera ao Abjecionismo um alcance sempre derivado da primeira manifestação de intenções, representada por esses dois nomes.

Pacheco opta por partir do vocabulário abjecionista para fazer dele uma coisa totalmente diferente. A divergência passa pela inversão da ordem da relação entre o sujeito e o conteúdo da formulação abjecionista: tomada como estabelecida nos seus pressupostos por Cesariny, e por isso mesmo reconduzida, no máximo, a uma cooperação produtiva com a ânsia de surrealidade, a via abjecionista torna-se em Pacheco dependente da singularidade prévia de um autor com um projeto e uma estratégia tão específicos que são reconhecidos por todos, projeto esse que lhe permite absorver as formulações abjecionistas fundamentais adaptando-as aos seus propósitos.

O episódio que lança agressivamente o tipo de Abjecionismo defendido por Luiz Pacheco é, ao mesmo tempo, uma provocatória intromissão numa iniciativa de Cesariny: o lançamento da antologia 
Surreal-Abjeccion (ismo). Se Cesariny idealizou para essa antologia uma espécie de terreno amplo no qual se encontrariam representantes de várias correntes acossadas pelo regime, Pacheco deu ao seu texto, "O Que é o Neo-Abjeccionismo", um tom absolutamente individualista, no qual os tópicos fundamentais da problemática abjecionista parecem coincidir com a sua própria experiência e, através dela, conhecer um novo alcance e uma expansão renovadora. É a emergência de uma nova faceta possível do Abjeccionismo que nesse texto se opera, conduzindo o seu discurso a uma simbiose perfeita com as exigências da vitalidade libertina.

Como assinala António Cândido Franco, trata-se do reconhecimento de que, sendo a abjeção e a neoabjeção formas de "rejeição social daquele que se consagra à conquista da liberdade" (FRANCO, 2016, p. 339-340), é nos acidentes particulares do percurso de Pacheco e sobretudo no conteúdo libertino que a todos percorre que mais adequadamente se poderá encontrar o prolongamento do discurso abjeccionista. O texto "O que é o Neo-Abjeccionismo" suscita surpresa na medida em que se propõe explicar ao público o sentido de um conceito no momento em que estava em curso a apresentação de uma obra resultante da conjugação de outros dois. Essa aparição de Pacheco no espaço que Cesariny pretendia fixar para a proposta abjecionista deixa abertas duas vagas: a expansão integradora que corresponde à proposta desenvolvida por Cesariny na sua antologia iconoclástica, que, associando representantes dos vários grupos surrealistas portugueses, deixava evidente a dependência do Abjecionismo em relação aos vários arredores do Surrealismo português; e a releitura de Luiz Pacheco, que faz do Abjecionismo uma espécie de organismo autónomo relativamente aos vários ismos anteriores e contemporâneos, incluindo aquele que convocava para dele se demarcar num libertino e inclassificável grito emancipador ${ }^{1}$.

A abjeção, neste texto, não é exclusivamente o produto de uma condição sociopolítica e dos respetivos constrangimentos colocados ao

\footnotetext{
${ }^{1} \mathrm{O}$ estatuto deste texto nas repercussões da atividade de Luiz Pacheco nos surrealistas e nos abjecionistas pode medir-se, não apenas na cisão entre Cesariny e Pacheco, a que fizemos menção, mas também numa passagem plena de ironia, mas com precisão cirúrgica, de Pedro Oom, na "Pequena História Cronometrada dos Dádás e Surrealistas de Cá": "Exceptuando Almada Negreiros, dádá avant la lettre e dadá comendado, e Mário Cesariny, surrealista avant la plume, nenhum dádá ou surrealista o foi nos terrenos lusíadas antes de Luiz Pacheco (...) Assim se tornou Luiz Pacheco no primeiro dádá português. Dessa data em diante, nunca mais Luiz Pacheco desmereceu dos seus manes mais queridos, Al Capone e Dadão, passando a constituir ele só a guarda avançada do mais puro e incorrupto dádá, com actuações de um desassombro e audácia, verdadeiramente única, neste mosso meio provinciano e timorato" (OOM, 1980, p. 84).
} 
sujeito, mas também uma manifestação das opções pessoais na composição de uma biografia. Desse modo, fatores muito diversos podem conjugar-se numa vasta panorâmica, que envolve a morte de familiares, dramas amorosos, acidentes de percurso derivados de excentricidades biográficas, como o desaparecimento dos filhos, e mesmo a morte da figura tutelar que paira em todo este texto, António Maria Lisboa. É o conjunto desses obstáculos e lacunas que determina uma exaustão moral da qual brota a consciência aguda do miserabilismo e, com ele, de si enquanto ser abjeto:

Perdi mãe e perdi pai, que estão no cemitério de Bucelas. Perdi três filhos - a Maria Luísa, o João Miguel, o Fernando António -, que estão vivos, mas me desprezam (e eu dou-lhes razão). Perdi amigos. Perdi o Lisboa; a mulher, a Amada, nunca mais a vi. Perdi os meus livros todos! Perdi muito tempo, já. Se querem saber mais, perdi o gosto da virilidade; se querem saber tudo, perdi a honra. Roubei. Sou o que se chama, na mais profunda baixeza da palavra, um desgraçado. Sou, e sei que sou. (PACHECO, 1998, p. 139)

No entanto, este panorama, desenvolvido num misto de contraste com os valores comuns, conivência exacerbada com os excessos cometidos e uma série de constrangimentos que determinaram algumas das escolhas, é convertido num valor - que também se desenvolve a partir do contraste relativamente aos padrões comuns e, sobretudo, em função do mito coletivo que se foi construindo a seu respeito, condicionando escolhas e exacerbando os excessos cometidos - corresponde à exaltação de uma riqueza pessoal que lhe confere exemplaridade única e irrepetível, merecendo, portanto, ser convocado oralmente e depois por escrito. De facto, a negatividade com que exprime as sucessivas perdas que foram conformando a sua existência são encaradas como um resultado necessário do próprio devir e, desse modo, justificam as transfigurações por que foi passando e o impacto destas na sua criação literária, produto direto de uma sinceridade própria de quem sabe aceitar-se plenamente pelo que é.

É dessa plena identificação com a própria contingência que emerge a estreita simbiose entre a figura do libertino e a poética da abjeção: "Mas, alto lá! sou um tipo livre, intensamente livre, livre até ser libertino (que é uma forma real e corporal de liberdade), livre até à abjecção, que é o resultado de querer ser livre em português" (PACHECO, 1998, p. 139).

Os termos sublinhados por Pacheco são fundamentais, conduzindo, na sua conexão, a um entendimento específico das 
circunstâncias a partir das quais a liberdade passa a ser um estado que se procura e que só se conquista através de uma sobrevivência ativa, mesmo que degradante.

A abjeção resultante do desejo de ser livre fazendo frente às amarras colocadas à plena autodeterminação alarga-se aos meios através dos quais essa vivência pode e deve ser transmitida. A dificuldade de se conseguir expressar "em português" um determinado ponto de vista deriva diretamente do contexto de opressão e de vigilância incessante que enquadra a atmosfera identificada com um vómito permanente, verdadeira regurgitação de ideias mimetizadas ao infinito, em vista da qual o indivíduo autónomo adquire a plena consciência do estado de menorização a que foi conduzido e dos procedimentos abjetos praticados pelo paradigma vigente. A afirmação de um agir divergente, passando também pelo recurso à palavra dita e sobretudo à palavra publicada, é, neste texto, assumida em todos os seus alcances: “O Que é o NeoAbjeccionismo" é, em simultâneo, a exposição de uma série de atos e práticas pouco convencionais, um texto no qual essas condutas são orgulhosamente associadas a uma interpretação pessoal da liberdade e uma performance através da qual se pretendia, por via da leitura, desencadear reações por parte do público ${ }^{2}$.

Ser livre em Portugal, segundo Pacheco, parece corresponder a uma forma de sobreviver em contraste com a grande maioria dos seus interlocutores, abandonados a um gregarismo monótono: "julguei que podia, era possível, ser livre e salvar-me sozinho, no meio de gente que perdeu a força de ser (livre e sozinha), e já não quer (mui pouca quer) salvar-se de maneira nenhuma" (PACHECO, 1998, p. 139). A configuração de um percurso vital neo-abjeccionista implica uma aceitação do risco e da perda, na medida em que não parece possível encontrar quem opte pela mesma revelação de si até às últimas consequências, assente no valor cimeiro da exemplaridade. Trata-se da expressão máxima da seguinte passagem de "Erro Próprio", de António Maria Lisboa, lida por Pacheco em clave libertina:

\footnotetext{
${ }^{2}$ Recorremos, neste contexto, à pioneira teoria de J. L. Austin a respeito do modo como determinadas formas de recurso às palavras se encontram deliberadamente implicados num projeto de intervenção no real, correspondendo não apenas à descrição de ações, mas ao que António Maria Lisboa designou como "palavras-actos" numa carta dirigida a Cesariny (LISBOA, 1995, p. 291-292) e por este tomada como máxima no texto "Mensagem e Ilusão do Acontecimento Surrealista" (CESARINY, 1997, p. 239).
} 
Nós sabemos: somos um erro- mas a consciência disso isola-nos do erro alheio. Qualquer que seja a conduta humana não é falsa nem verdadeira- (embora se possa pensar e sentir sempre errada).

(...) A investigação deste Universo, de que falo, e há tal como o vou descobrindo e não como os outros o encontraram, fá-la-ei como me aprouver, sem ter que dar contas a ninguém, nem pedir licença para o que possa dizer, pois desde o início é para mim mesmo que afirmo e o que afirmo, antes de mais, para meu uso pessoal. (LISBOA, 1995, p. 27)

Assim, o reconhecimento de uma conduta necessariamente errada - como todas, de resto - implica que o indivíduo encontre uma forma particular de existir para mais amplamente investigar o real, do mesmo modo que se estrutura na convicção de que não pode responder pelos erros alheios, mas também não pode ser condicionado pelos seus padrões comportamentais. A exemplaridade é a colocação do indivíduo ao serviço da sua própria revelação, contributo ativo na exploração dos múltiplos possíveis de um mesmo universo.

Se, a certa altura, o texto exprime as consequências do egotismo inerente a esta visão, que são também o preço a pagar por querer ser livre em Portugal, dado que pede a colaboração dos demais no sustento de seres dependentes de si, os filhos e a mãe adolescente, a possibilidade de continuar a ser livre em português no texto em que esse pedido ocorre não esgota nem suspende a exibição da abjeção social nas suas mais dolorosas repercussões. O autor que parece reconhecer o esgotamento da sua performance é o mesmo que se oferece como responsável por um texto no qual esta é levada às últimas consequências, dada a rigorosa descrição de todos os seus reflexos; os erros de conduta tornam-se, também eles, emblemas de uma personagem literária, como se fossem transferidos do sujeito que os nega para o domínio da intervenção desse mesmo sujeito no palco oferecido pelo papel para a fixação de um sortido de biografemas.

Este entrecruzar de domínios culmina no momento em que procede a uma acusação severa aos interlocutores através das correntes literárias por estes representadas, cujo impacto concreto no combate aos aspectos abjetos do quotidiano deixava a desejar:

É natural que alguns de vocês tenham filhos. Que haja, talvez, talvez por certo, mães e pais nesta sala. Não sei se já ouviram os vossos filhos dizerem, a sério, que estão com fome. É natural que não. Mas eu digolhes: é essa uma música horrível, uma música que nos entra pelos 
ouvidos e me endoidece. Crianças que pedem pão (pão sem literatura, ó senhores!) pão, pãozinho, pão seco ou duro, mas pão, senhores do surrealismo, e do abjeccionismo, e do neo-realismo e mesmo do abstraccionismo! (PACHECO, 1998, p. 140)

Estamos no âmbito do debate em torno do verdadeiro significado de "intervir" e de "atuar", traço que Osvaldo Silvestre associa ao dispositivo mitológico com que Luiz Pacheco procurou construir para si um espaço absoluto no domínio do literário e que "confere uma profunda coerência àquilo a que, em vez de 'Obra', será preferível chamar 'Intervenção' ou 'Actuação', na medida em que faz da indistinção entre 'vida' e 'escrita' o seu motor", tendo como única lei a ética da própria extensão convertida ao vivido pela escrita" (SILVESTRE, 2010, p. 34). A possibilidade de se considerar a criação de Luiz Pacheco como uma 'Intervenção' ou 'Atuação' implica a apologia da furiosa indistinção entre vida e obra, tendo sempre o risco calculado no horizonte e a possibilidade de esse jogo conduzir a efeitos delicados para o experienciador - por exemplo algumas das perdas descritas em "O que é o Neo-Abjeccionismo" e que se devem exclusivamente a escolhas pessoais - que é reiterada na crítica ao conteúdo de $A$ Intervenção Surrealista, em nome de uma outra compreensão do que significa "intervir".

Numa carta em que procura inteirar-se do conteúdo de $A$ Intervenção Surrealista, Pacheco acaba por estabelecer com precisão o contraste entre os pontos de vista que, a seu ver, caracterizavam as respetivas disposições perante a gravidade da resistência face ao meio envolvente:

Ninguém quer a tua morte, e eu muito menos. Os que a queiram ou querem, ainda, são uns distraídos que fingem que o Poeta de Corpo Visível pode morrer. Disto, porém, a fingirmos que estes tais dispõem da cadeia e do hospital, para nos albergar a mal ou a bem (por bem), vai um grande passo. Uma fatal distracção. Foste sempre assim, não querendo prever que o nosso caminho dava para aí. (...) Porém, eu não esqueço, nem estou distraído: escolhi mas não consinto sem muito escucinhar e até ao fim que esses tais outros achem isto natural. (...) $\mathrm{O}$ pior, Mário, é estar parado ou voltar estupidamente atrás. É isso que os melhores não nos perdoam. (PACHECO, 1974, p. 263-264) 
Pacheco procura acentuar a distinção entre duas etapas do percurso de Cesariny, reconhecendo numa delas, correspondente à poética de Corpo Visível, uma verdade que não pode de modo algum ser suplantada pelo jugo das instituições dominantes, adquirindo o efeito designado por Carlos Reis como "sobrevida de uma personagem" (REIS, 2015). Trata-se de uma compreensão da poesia que, conforme Pacheco sintetiza no final desse documento, a distingue da mera ficcionalidade para lhe conferir um estatuto intermédio, no qual se produz o próprio mito para o extrair aos mecanismos da mitologia dominante. Neste caso, o mito de si próprio como figura de sobrevivência abjecionista:

A ficção não é a poesia. Na ficção inventa-se, na poesia confessa-se. Ali generaliza-se por dedução aqui individualiza-se por megalomania. São coisas bem diferentes. Por trás da Poesia, o Poeta ou um aldrabão. Por trás do mito, um crítico ou um moralista. Talvez um farsante. Mas nenhum de nós está agora em condições já de o verificar. (PACHECO, 1974, p. 264)

Em suma, e dado que Pacheco recorre à noção de crítica conforme idealizada por António Maria Lisboa, a verdade de Cesariny, que em Corpo Visível estivera plenamente expressa e por isso ultrapassara a mera ficção, é considerada equivalente à permanência do mito pessoal em Pacheco, para o qual só existe uma forma de permanecer fiel ao seu próprio projeto: "contar com a polícia e denunciá-la onde ela existe, é já ser da polícia?! Ou contra a polícia? Pensar que nos possa bater à porta, mas fugir adiante se possível, negando-a o mais possível por actos em que ela existe mas fingimos estar ausente, é ser da polícia?!" (PACHECO, 1974, p. 264).

Não surpreende, em vista dessa expressão de coragem que concebe a tentativa de preservação pessoal, mas lhe sobrepõe o imperativo de evidenciar a presença da realidade policiária e, através dela, dos valores promovidos pela sociedade, que Pacheco escolha os textos "Aviso a Tempo por Causa do Tempo" e Autoridade e Liberdade são Uma e a Mesma Coisa, ausentes de $A$ Intervenção Surrealista, para exprimir a aparente abdicação de Cesariny $^{3}$. Se o primeiro caracterizava a relação dos surrealistas

\footnotetext{
${ }^{3}$ A centralidade desses textos no ataque, que perpassa várias cartas e documentos, encontra-se expressa com maior veemência nos textos "O caprichismo interventor do sr. Mário Cesariny" e "Da Intervenção à Abjecção". No primeiro, Pacheco condena o facto de Cesariny não ter aproveitado adequadamente o livro para rebater a vigilância permanente a que se encontravam sujeitos os mais dotados escritores do seu tempo, sobrevalorizando uma série de incidentes sem grande expressão em detrimento de exemplos vigorosos de
} 
portugueses com o seu contexto afirmando que "sendo individualmente e portanto abjeccionalmente desligados das normas convencionais, (...) delas daremos por vezes testemunho e mesmo ensino" (LISBOA, 1995, p. 53), o segundo deixava claro que "Ser-se livre é possuir-se a capacidade de lutar contra o que nos oprime. Quanto mais perseguido mais perigoso. Quanto mais livre mais eficaz" (CESARINY, 2015, p. 85). Para Pacheco, essas duas afirmações de propósitos, sobretudo se devidamente conjugadas, continuavam plenamente válidas.

É esse perfil que Pacheco procurava na altura fixar para Cesariny, integrando-o - ou a algumas das suas manifestações criativas mais contundentes - no âmbito da poética Neo-Abjecionista libertina. O que fica evidente num texto que terá sido a gota de água nas relações tumultuosas entre ambos desde final da década de 50, "Comunicado ou Intervenção da Província" (1966). Pacheco, propondo-se homenagear a coragem inabalável de Cesariny tendo como pretexto a recente edição de $A$ Cidade Queimada (1965), remete diretamente para o seu paradigma interpretativo do papel do libertino numa sociedade abjeta:

Estamos enterrados desde há perto de dois mil anos numa civilização castradora, a nossa por nosso azar, que despreza o corpo, o castiga com torpezas várias, trabalhos inúteis, o crucifica à martelada, sendo preciso, o consome estupidamente fora e abaixo das suas próprias funções e beleza -até à chegada infalível do cangalheiro. / ÓDIO AO CORPO! /É o que eles nos ensinam e comandam desde os bancos da escola. / AMOR AO CORPO. (...) O Poeta como vidente, quase como apóstolo dá-nos notícia e exemplo duma Moral Nova, mais livre, para dizer a palavra exacta: LI-BER-TI-NA. E o seu poema marca o roteiro dos perigos e angústias de como podemos lá chegar, ou de como ele já lá chegou. Não é fácil, não julguem. (PACHECO, 1974, p. 242-244)

$\mathrm{O}$ “Neo-Abjecionismo", como a própria libertinagem, é dado como resultante de um complexo diálogo entre questões pessoais e alheias, 
empenhando toda essa matéria-prima acumulada numa conversão literariamente significativa do exemplo dado na vida.

Ao longo de duas décadas, o Abjecionismo marcou a definição de um importante território de disputa em torno das condições de acesso autor literário à plena liberdade das suas manifestações criativas. Importa por isso realçar que, sem esgotar as diversas facetas e vocabulários característicos do movimento surrealista, incluindo se considerarmos os diversos usos da ideia de abjeção entre autores portugueses, como demonstrado em contributos anteriores ${ }^{4}$, é no Abjecionismo que se podem encontrar muitos dos mais significativos reflexos do amplo leque de leituras metacrítica em que assenta o património discursivo do movimento surrealista em Portugal. A problematização do autor, como procurámos evidenciar, é o núcleo fundamental dessa abordagem, motivando as mais diversas querelas relacionadas com o grau de radicalidade da sua postura crítica face a uma condição humana marcada pela contingência e a contextos políticos sobrecarregados por constrangimentos. Seria em parte essa a herança deixada por futuras gerações a braços com outros momentos nos quais o questionamento, a crítica, a revolta identitária ou a exposição livre das peculiaridades vitais se posicionam como base fundamental de um discurso poético de libertação e de exemplaridade. ${ }^{5}$

\footnotetext{
${ }^{4} \mathrm{Na}$ tese de mestrado, estudámos a problemática do abjeto tendo em conta as suas manifestações em autores relacionados com o Surrealismo em Portugal, de António Pedro, Fernando Lemos e Alexandre O’Neill, ligados ao Grupo Surrealista de Lisboa, aos diversos intervenientes no grupo dissidente Os Surrealistas e no âmbito do Grupo do Café Gelo (SOUSA, 2016). No doutoramento, aprofundámos a discussão do assunto, conferindo mais destaque à emergência da singularidade libertina de Luiz Pacheco (SOUSA, 2019).

${ }^{5}$ É em Fernando Guimarães que se podem encontrar os mais significativos exemplos de definição dessa posteridade. Lendo a ampla rede de referentes de poetas como Joaquim Manuel Magalhães, Rui Baião, Al Berto, Paulo da Costa Domingos, entre outros, em função do que entre nós foi o Surrealismo-Abjecionismo, reatualizado com novos contributos nacionais e internacionais (GUIMARÃES, 1989, p. 139-145), Guimarães relaciona a antipoética abjecionista com a via mais aguerrida, politizada e libertária do movimento surrealista internacional ou mesmo com autores e grupos com ligações à órbita surrealista mas de algum modo independentes deste, prolongando-se no ideal literário de Vítor Silva Tavares na \&etc e em alguns projetos seguidores, como a Frenesi, a que arriscamos acrescentar mais contemporaneamente o caso da Averno e a poética dos Poetas sem Qualidades (GUIMARÃES, 2004, p. 141-154).
} 


\section{REFERÊNCIAS}

CESARINY, Mário (org.). Surreal-Abjeccion (ismo). Lisboa: Minotauro, 1963. CESARINY, Mário. O Jornal do Gato. 2a edição. Lisboa: Assírio \& Alvim, 1974.

CESARINY, Mário (org.). A Intervenção Surrealista. 2aa edição. Lisboa: Assírio \& Alvim, 1997.

CESARINY, Mário. Cartas de Mário Cesariny para Cruzeiro Seixas. Ed. Perfecto E. Cuadrado, António Gonçalves e Cristina Guerra. Vila Nova de Famalicão: Fundação Cupertino de Miranda, 2014.

CUADRADO, Perfecto E. “Introdução em três movimentos”. In Perfecto E. Cuadrado (org.). A Única Real Tradição Viva. Antologia da Poesia Surrealista Portuguesa. Lisboa: Assírio \& Alvim, 1998, p. 7-65.

CUADRADO, Perfecto E. “Entre Nós e as Palavras, Mário (apresentação cordial)". In Mário Cesariny. Poesia. Ed. Perfecto E. Cuadrado. Lisboa: Assírio \& Alvim, 2018, p. 9-25.

CESARINY, Mário. As Mãos na Água, a Cabeça no Mar. 3ae ed. Lisboa: Assírio \& Alvim, 2015.

FRANCO, António Cândido. "Da Circunstância e da Ética do Abjeccionismo". A Ideia. Revista de Cultura Libertária, no 77-80, outono 2016, 2016, p. 306-319.

GUIMARÃES, Fernando. O Modernismo Português e a sua Poética. Porto: Lello, 1999.

GUIMARÃES, Fernando. Simbolismo, Modernismo e Vanguardas. $3^{\mathbf{a}}$ ed. Lisboa: INCM, 2004.

LISBOA, António Maria. Poesia. Lisboa: Assírio \& Alvim, 1995.

OOM, Pedro. Actuação Escrita. Lisboa: \&etc, 1980.

MARTINS, Fernando Cabral. Mário Cesariny e o Virgem Negra. Lisboa: Documenta, 2016.

MARTINS, Fernando Cabral. "À Luz da Ampola Miraculosa". In Joana Meirim (org). E a Minha Festa de Homenagem? Ensaios para Alexandre O'Neill. Lisboa: Tinta da China, 2018, p. 49-58. 
MARTUSCELLI, Tania. Mário-Henrique Leiria e a Linhagem do Surrealismo em Portugal. Lisboa: Colibri, 2013.

MOURÃO, José Augusto. "Surrealismo e Tecnossurrealidade: rotas convergentes?". Atalaia - Intermundos, nº 10/11, 2002, p. 31-38.

PACHECO, Luiz. Exercícios de Estilo. 3aㅡ ed. Lisboa: Estampa, 1998.

PACHECO, Luiz. Pacheco versus Cesariny. Folhetim de Feição Epistolográfica. Lisboa: Estampa, 1974.

PETRUS. Os Modernistas portugueses - escritos públicos, proclamações e manifestos, vol. III. Dos Independentes aos Surrealistas. Porto: C.E.P, 1962.

REIS, Carlos. Pessoas de Livro. Estudos sobre a Personagem. Coimbra: Imprensa da Universidade, 2015.

ROCHA, Clara. O Cachimbo de António Nobre. Lisboa: Dom Quixote, 2003.

SILVESTRE, Osvaldo. “Mitologias Maiores e Menores". Público - Caderno Ipsilon, 12 de fevereiro 2010, p. 34.

SOUSA, Rui. A Presença do Abjecto no Surrealismo Português. Lisboa: Esfera do Caos, 2016.

SOUSA, Rui. Do Libertino: Revisões de um conceito através do caso de Luiz Pacheco. Dissertação de Doutoramento apresentada à Faculdade de Letras da Universidade de Lisboa, 2019. Disponível em :

https://repositorio.ul.pt/handle/10451/41724).

Recebido em 26 de julho de 2020

Aprovado em 19 de outubro de 2020

Licença: (ㄷ) (i) (우

Rui Daniel Sousa

Universidade de Lisboa. Centro de Literaturas e Culturas Lusófonas e Europeias

Doutorando em Estudos Literários, variante Literatura Portuguesa, na Faculdade de Letras de Lisboa, Portugal.

Contato: ruidnsousa@gmail.com

(iD: https://orcid.org/0000-0002-2810-0092 